\title{
Poetic Justice and Its Inconsistencies Poetry As Tool for Moral Education in Ancient Greece
}

\author{
Shiyi Zhu ${ }^{1, *}$ \\ ${ }^{1}$ Department of Humanities and Social Science, Beijing Language and Culture University, Xueyuan Street, Haidian \\ District, Beijing, China \\ ${ }^{*}$ Corresponding author. Email: $18987354409 @ 163 . c o m$
}

\begin{abstract}
By examining Hesiod's didactic poem, Works And Days and Homer's epic, the Iliad and the Odyssey, this essay argues that although poets in ancient Greece encourage people to live a just life, this moral education has its limitations because of its inconsistency of its attitude towards gods' judgments. On the one hand, in Works And Days, the Iliad, the Odyssey and the elegies the poets educate people to live a just life because gods such as Zeus judges people's behaviors, awarding just people and cities while punishing those who do unjust ones. But on the other hand, the poems do not always stick to this pattern of divine justice and sometimes say either that misfortune can go to good people and bad people indiscriminately under gods' arbitrary will or that unjust people can get away from punishments by manipulating gods' judgments. This inconsistency in the poems makes a just life less desirable in the mind of young people and potentially gives way to unjust deeds.
\end{abstract}

Keywords: Ancient Greek Poetry, Moral Education, Works and Days, Republic

\section{INTRODUCTION}

In ancient Greek society, poems are used not just for entertainment and artistic enjoyment but for social education such as teaching of theology, social ethics and cultural understanding[1]. One of the important aspects of this moral education is teaching social justice. Justice, translated from "dikê" in Homer and Hesiod's poems, refers to moral codes that are seen to be appropriate in a society, and a man of justice is "a man who does the appropriate thing" according to these social norms, while violating these appropriate things is viewed to be unjust[2].

As a main method of teaching the notion and criteria of morality to the public, the poems in the ancient Greece, especially the poems of Homer and Hesiod, are responsible for teaching justice, to be more specific, for teaching what is right and what is wrong, what is appropriate and what is inappropriate. These norms of justice are taught through the examples in the poems.

\section{POEMS' EDUCATIONAL FUNCTION IN ANCIENT GREECE}

\subsection{Divine Justice: Works and Days}

To examine the educational function of poems of ancient Greece, we need to first look at Works and Days, the didactic poem written by Hesiod talking about the divine justice of Zeus. Divine justice is the criteria of behavior made by God Zeus, whose awards and punishments to different human behaviors lead to prosperity or decadence of an individual, a community, or an entire human race.

Zeus' divine punishment lies first in individual level. In Hesiod' Works And Days, Zeus functions as an authority to give awards to just people or cities who earn wealth by work and to punish those who earn wealth through unjust ways, such as plundering. For example, the poem teaches that by working hard, individuals can be granted a happy and respectful life by Zeus. For a just man, "to him wide-seeing Zeus gives prosperity" [3]; by contrast, for those who gain wealth through unjust ways, "the gods easily bring him low"[3]. 
Another benefit of being just is that individual efforts can in the end contribute to the development of the whole community. Hesiod says "for those who...do not deviate from what is just, their community flourishes, and the people blooms in it" [3], relating the morality of the individual to the future of the community. This benefit is further emphasized in the contrast between just city and unjust city. The just city, which is full of just people, is peaceful, rich in food, fertile, free from unjust plundering, and people there live a happy life [3]. In contrast, the unjust community, which is full of "those who occupy themselves with violence and wickedness and brutal deeds", receives "retribution" from Zeus, including famine, plague, infertility, and disasters[3]. This big contrast between two cities educates the importance for citizens to be just.

Furthermore, Hesiod even indicates that by being just, the whole human race can avoid declining. Canevaro once observed this in the poet's careful use of verb tense: although Hesiod points out that "now it is a race of iron", the worst race in the all five ages, when he is describing the decline after iron age, "Zeus will destroy this race of men also"[3], Hesiod transfers from present tense to future tense[4]. This change of verb tense indicates that although men are living in a bad state, as Hesiod later said later "I do not expect resourceful Zeus is bringing this to pass yet"[3], the worst, the destruction of Zeus, has not come yet, and people still have chance to avoid being destroyed by living a just life. This hope gives people a motivation to be just and receive the poet's education. Therefore, as a didactic poem, Works and Days uses the awards and punishments of God, Zeus, to teach the criteria of human behaviors.

\subsection{Heroes as Moral Examples: The Iliad}

In order to encourage soldiers to fight bravely, ancient poems show that soldiers can earn glory and immortality through fighting bravely. As said by Plato, the poet "clothes all the great deeds accomplished by the men old of glory, and thus educates those who come after"[5], morality for warriors encourage them to require glory. Poems can establish good modals for soldiers, give examples of what good soldiers should be, and remind soldiers of their social responsibility. The poems tell the soldiers that fighting in the battlefield is what is expected from the society. Homer's epics, the Iliad and the Odyssey, create ideal heroes as models for soldiers in a moral sense. Homer's heroes explain what does it mean to be excellent soldiers, and what does it benefit individuals and community.

First, Homer's epics teach that soldiers fight because they have certain social responsibilities, and they need to fulfill these responsibilities in order to be just. For example, in the Iliad, during the talk between Sarpedon and Gaucus, Sarpedon points out that they must "take our stand among the foremost...so that may a one of the mail-clad Lycians may say ...they eat fat sheep and drink choice wine, honey-sweet: but their might too is noble, since they fight among the foremost Lycians."'[6] This remark relates the benefit given by the society and the corresponding responsibilities. Similarly, the hero in the Iliad, Achilles, is also highly aware of his social responsibility. When he talked about why he fought, he said "my father sent me to Troy...to be always among the bravest, and hold my head above others, not shaming the generation of my fathers."[6] Therefore, the figure of Achilles creates a standard and a social expectation of individuals as soldiers.

Similarly, in the Iliad, another hero, Odysseus also said that "it is the cowards who walk out of the fighting"[6], pointing out that the choice of soldiers, which means to fight or not, is closely related to the attitude of society towards them, and this remark reminds all the soldiers that being coward in the battle will bring disgrace to their reputation. Therefore, Homer's heroes give examples of how soldiers should behave in battle, and highlight the social attitude and social consequence of personal choice, relating one person's honour to his family and the whole society.

\subsection{The Best Life and The Worst Life: Elegies and Iambic Poetry}

Similar expectations on soldiers can also be found in Greek elegies and iambic poetry. Tyrtaeus's elegies tell about what should people do in the battlefield, giving people moral codes for warriors. In Tyrtaeus's elegies, the poem points out the best life and the worst life for the soldiers. In fragment ten, he points out that the best life is "a brave man fighting for his fatherland", while the worst life is "to leave one's town and fertile farmlands for a beggar's life"[7].

To make these two choices more appealing, the poet uses different images to illustrate these two kinds of lives. For "the worst life", the poet gives a shameful sight of an unwelcome escaper from the war, "not be welcome anywhere he goes, bowing to need and horrid poverty, his line disgraced, his handsome face belied; every humiliation dogs his steps"[7]. This detailed and descriptive pathetic image of an escaper emphasizes an ugly and unwelcome consequence of escaping from the war, making people emotionally move away from it. This pathetic image of the bad example is immediately followed by the glorious image of a young hero who dies yet "draws men's eyes and women's hearts". With the contrast of these two images, the poem finally concludes that "let every man then, feet set firm apart, /bite on his hip and stand against the foe"[7].

Similarly, in fragment eleven, the poet first the bad image of the escaper, "those who run, lose all esteem" with "a shameful sight to see him lie/dead in the dust, 
the spear-point in his back"[7]. This disgraceful and disgusting image of a coward on the battlefield warns soldiers that they should not be cowards in the war. In fragment twelve, the poet further shows the rewards a soldier can get by fighting bravely, such as reputation and fame ("his death is mourned alike by young and old"), immortality of glory ("his name and glorious reputation never die;/he is immortal even in his grave"), a happy old age ("he grows old in celebrity, and no one thinks/to cheat him of his due respect and rights")[7]. Therefore, by showing the rewards of fighting in the war and showing the bad consequence of escaping from the war, the poet educates the soldiers that they should fight bravely on the battlefield.

\section{INCONSISTENCIES IN POETIC JUSTICE AND SOCRATES' CRITICISM}

\subsection{Questionable Divine Justice in Works and Days}

From the above discussions, we know how poets in ancient Greece use God's authority and examples in poems to teach moral justice. However, the problem in this moral education is that Homer and Hesiod are not always consistent with their own words, and God's judgments, to be more specific, Zeus' judgments are not always just. This inconsistency can first be observed in some parts of Works And Days, where the poet is uncertain of whether the judgments of gods will be just or not.

Many scholars such as Perysinakis have noticed that there is a "lack of unity" in Works And Days [8], which means that although the poet claims that just people absolutely receive award from gods while unjust people absolutely receive punishments, in some parts of the poem bad things happen to good and bad people indiscriminately. For example, Gagarin notices that there is an "arbitrary" part of Zeus' power from the very start of the poem when Hesiod says "easily he makes strong, and easily he oppresses the strong"[9]. This line only emphasizes Zeus' will but fails to emphasize clearly what kind of behavior Zeus will give punishments or awards, which indicates that Zeus' power is not certainly related to certain kind of behaviors, whether these behaviors are just or not.

This ambiguity is further strengthened in the later part of the poem. In many cases, the disaster of seafaring comes to some people not because those people are good or bad but only because Zeus "wants to destroy them" [3]. This indicates that in the poem, Zeus' behavior sometimes can have nothing to do with people's morality, and disasters can go to both good and bad people. The consequence of this ambiguity is that justice becomes less desirable.
This bad effect on moral education can be seen in the conversation between Socrates and Adeimantus in Plato's Republic. Adeimantus, Socrates' interlocutor, observes the bad effect of poets' inconsistency, saying that this will make young people less motivated to do just things. Adeimantus further points out that although poets "all go on repeating with one voice that justice and moderation are fine things"[5], they also say that the gods "assign misfortune and a bad life to many good people"[5], just as what is indicated in Works And Days. And this inconsistency has become, as said by Adeimantus, "the most wonderful of all these arguments"[5] to support the idea that justice is undesirable.

\subsection{Moral Inconsistency in the Iliad}

The moral inconsistency can further be observed in poems of Homer, in which bad people can even get away with their wrong-doings.

For example, in the Iliad, rituals and magic can influence the judgment of Gods, which means that awards and punishments from Gods are not always made based on fixed standards of morality. For example, Phoenix told Achilles that

"Even the gods, I say, with incense, soothing vows, /with full cups poured and the deep smoky savor/ men can bring them round, begging for pardon/ when one oversteps the mark, does something wrong."[6]

In this case, the role of God in this case greatly differs from the strict judge created by Hesiod, and it is uncertain whether bad people will get punishments or not. The consequence of this is that people are more daring to do unjust things, because they know that their wrong behaviors will not be punished.

In Plato's Republic, Adeimantus notices that in this case, Hades, the underworld where bad people "pay the penalty for crimes committed"[5], would lose its deterrence on unjust behaviors. Adeimantus especially emphasizes this bad effect on the minds of young people by imagining one young man defying punishments in Hades with stories told by "poets and prophets"[5], who said in the poems that "mystery rites"[5], such as the "incense, soothing vows"[6] in the Iliad, "have great power"[5], so that unjust deeds will no longer lead people to "the penalty for crimes committed"[5] in Hades. In this case, young people have no reason to resist the temptation of doing unjust things anymore, and the moral education of poets is corrupted.

\subsection{Double Attitudes Towards Death}

This inconsistency in divine justice could further be observed in the poets' attitude towards death, especially death on the battlefield. In Plato's Republic, Socrates express his skeptical attitude towards this problematic 
education of military morality. According to Socrates, in order to make soldiers courageous in the battlefield, the poet should not make them be afraid of death. However, the Iliad, which should have provided education of glorious death on the battlefield, contains many images in which soldiers die with a horrible image. This epic also sometimes devote hundreds of lines and numerous rhetoric devices to describe the horror of the underworld, Hades.

For example, Socrates noticed that there are many cases in Homer's epic and Hesiod's poems that depict Hades into "an awful cave" full of "shadows" and with souls "lamenting its fate"[5]. Socrates has especially mentioned about Hesiod's Theogony, in which Hades, the underworld is described as a place "loathsome and dank, which even the Gods abhor."[10] He has also refers to Achilles' conversation with Odysseus in Hades, the underworld, in which Achilles, the one who should have been proud about his death on the battlefield, told Odysseus that "I should choose, so I might live on earth, to serve as the hireling of another, some landless man with hardly enough to live on, rather than to be lord over all the dead that have perished."[11] Responding to these descriptions, Socrates said in Republic that "we must supervise such stories and those who ell them, and ask them not to disparage the life in Hades in this unconditional way, but rather to praise it"[5]. This disparagement of death, according to Socrates, will prevent young people from preferring death to "defeat in battle in battle or slavery"[5].

Therefore, we can see that poets actually hold double attitudes towards death in their poems. On the one hand, as in the fragments of Tyrtaeus discussed above, the poets praise death by displaying glorious and honorable figures who die on the battlefield. On the other hand, as Socrates has said, "the more poetic they are, the less they should be heard by children or by men who are supposed to be free and to fear slavery more than death", the glories of death have been constantly corrupted by the horrible image of the underworld, which all the people, honorable or not, end up in. This double vision of death weakens the educational function of the poems and makes death less desirable.

\section{CONCLUSION}

In conclusion, ancient Greek poems encourage people to live a just life by showing them the benefits of being just and punishments of being unjust, but the ambiguity and inconsistency in the same works or in different works causes potential problems in moral education of citizens. Although Works And Days from the level of individual, city and humankind shows that being just can lead to great benefits, poets do not always stick to this belief. Its bad effect on moral education can be seen in Republic, where the arbitrary will of gods makes the benefits of justice undesirable and the changeable decisions of gods remove the deterrence of divine punishments. Therefore, young people are more likely to drift away from justice and do unjust things.

\section{REFERENCES}

[1] W.J. Prior, Virtue and knowledge: An Introduction to ancient Greek ethics, Routledge, 1991.

[2] Havelock, Eric Alfred., The Greek Concept of Justice: From Its Shadow in Homer to Its Substance in Plato, Harvard University Press, 1978.

[3] Hesiod, Works And Days, in: M. L. West (trans.), Theogony And Works And Days, Oxford University Press, 1999.

[4] Canevaro, Lilah Grace, Hesiod's Works and Days: How to Teach Self-Sufficiency, Oxford University Press, 2015.

[5] Plato, Republic, in: G. M. A. Grube (trans.), C. D. C. Reeve, Republic, Hackett, 1992.

[6] Homer, The Iliad, in: R. Fagles (trans.), Bernard Knox (intro.), The Iliad, Penguin Books, 1991.

[7] M.L. West (trans.), Greek Lyric Poetry, Oxford University Press, 2008.

[8] Loannis Perysinakis, Hesiod's treatment of wealth, Mètis.Anthropologie des Mondes Grecs Anciens, Vol.1, No.1, persee.fr. 1986, pp. 97-119. DOI: http://dx.doi.org/10.3406/metis.1986.866

[9] Michael Gagarin, The ambiguity of Eris in the Works and Days, in: Mark Griffith and Donald J. Mastronarde (Eds), Cabinet of the Muses: essays on classical and comparative literature in honor of Thomas G. Rosenmeyer, Atlanta: Scholars, 1990, pp.173-183. https://escholarship.org/uc/item/61d248b4

[10] Hesiod, Theogony, in: M. L. West (trans.), Theogony And Works And Days, Oxford University Press, 1999.

[11] Homer, The Odyssey, in: George E. Dimock (Eds), A. T. Murray (Trans.), Harvard University Press, 1995. 